\title{
Double-blind comparison of cimetidine and placebo in the maintenance of healing of chronic duodenal ulceration
}

\author{
K. D. BARDHAN, D. M. SAUL, J. L. EDWARDS, P. M. SMITH, \\ S. J. HAGGiE, J. H. WYLliE ${ }^{1}$, H. L. DUTHIE, AND I. V. FUSSEY
}

From Rotherham Hospital, Rotherham, University Hospital of Wales, Cardiff, Llandough Hospital, Penarth, University College Hospital, London, and the Royal Infirmary, Sheffield

SUMMARY Patients suffering from chronic duodenal ulceration were allocated at random to treatment with either cimetidine ( $400 \mathrm{mg}$ twice daily) or matching placebo for six months. Before entry to the trial all patients were shown to have healed ulcers on endoscopy. Most of the patients had participated in a one-month trial of cimetidine during which their ulcers healed. The trial showed that four of 29 patients relapsed on maintenance treatment with cimetidine, which therefore did not confer complete immunity from relapse. However, cimetidine treatment was very much better than placebo treatment, on which 18 of 31 patients relapsed. Of the 22 patients who relapsed clinically, 20 were submitted to endoscopy and 19 of these were shown to have ulcerated again. Endoscopy at the end of the trial showed that ulcers had also redeveloped in five of 28 asymptomatic patients. Length of previous dyspeptic history had no bearing on the results of the trial but there was evidence that relapse on placebo was less likely if the ulcer had originally healed on a high dose of cimetidine. Clinical relapse was associated with worsening duodenitis. Symptoms, clinical observation, and laboratory tests showed no important abnormalities in the patients.

Duodenal ulceration is a chronic recurrent condition; so long-term treatment with an agent known to promote ulcer healing may be expected to reduce the incidence of relapse. The $\mathrm{H}_{2}$-receptor antagonist, cimetidine, in doses of $0.8-2.0 \mathrm{~g} /$ day produces a significantly higher incidence of healing than does placebo treatment, the healing rate on cimetidine being $70-80 \%$ in most series (see, for example, Bodemar and Walan, 1976; Blackwood et al., 1976; Gray et al., 1977; Multicentre Trial, 1979).

We present an investigation of the effectiveness of cimetidine in maintaining symptomatic and endoscopic remission of chronic duodenal ulceration. The trial was begun in the latter part of 1976 and was completed about a year later. In the interval, others have published results of similar trials which also show the value of maintenance treatment with

${ }^{1}$ Address for correspondence: J. H. Wyllie, University College Hospital, London WC1.

Received for publication 14 September 1978 cimetidine (Bardhan et al., 1977; Bodemar and Walan, 1978; Gray et al., 1978; Hetzel et al., 1978).

\section{Methods}

PATIENTS

Outpatients who fulfilled the following criteria entered the trial. Complete ulcer healing (with or without resolution of duodenitis) was shown by endoscopy not more than 48 hours after stopping treatment with cimetidine 1 or $2 \mathrm{~g}$ /day or (in a few cases) matching placebo. Most patients had received this treatment over a four week period within a multicentre study of the effect of cimetidine on the healing of duodenal ulcers (Multicentre Trial, 1979) and for these the series was essentially consecutive, apart from the exclusion of patients known to have other gastrointestinal disease, or who had undergone ulcer surgery other than simple suture of a perforation. Pregnant and lactating women, and children under 16 years of age, were also excluded. All patients were in 158 
symptomatic remission and each gave his informed consent to the trial, which had the approval of local ethics committees.

Patients were randomly allocated to receive either cimetidine $400 \mathrm{mg}$ (two tablets) in the morning and at bedtime, or matching placebo. No other treatment was allowed except a standard antacid (unmarked Rennie tablets), which could be taken as frequently as required for the relief of ulcer pain which was not controlled by the trial medication. Each patient was provided with a diary card, on which was recorded antacid consumption and diurnal and nocturnal ulcer pain. Patients were seen every fortnight for the first eight weeks and then monthly for up to six months, the duration of the study. At each attendance the diary cards were inspected and unexpected or untoward symptoms were recorded, and blood was taken for a full blood count, platelet count, reticulocyte count, and estimation of plasma or serum transaminases, bilirubin, alkaline phosphatase, creatinine, urea, and urate. The urine was also tested for protein and sugar. Counts of returned tablets were not made but the patients were asked whether they had missed any doses. Endoscopic examination was performed before the trial and at the end of treatment, or when the clinician considered that symptomatic relapse had occurred. The presence or absence of ulceration was noted. Duodenitis was visually assessed on a four-point scale as follows: severity, $0=$ none, $1=$ slight, $2=$ moderate, 3 = severe; extent, $1=$ localised around ulcer, 2 = more than one area, $3=$ throughout duodenal cap. It was not possible to arrange for the endoscopists to be ignorant of the patients' symptoms, although they were, of course, blind as regards the treatment.

\section{Results}

Table 1 shows how many patients of either sex entered the trial, how many defaulted and had to be excluded, and how many of those who continued in the trial relapsed clinically. It also shows the results of the second endoscopy. However, this repeat endoscopy was declined by 10 of 38 patients who were asymptomatic at the end of the trial and by two of 22 patients who had relapsed clinically: this the table also shows.

Clearly, cimetidine was effective in preventing clinical relapse $\left(\chi^{2}=10.81, \mathrm{P}<0.005\right)$. Clinical relapse was almost synonymous with re-ulceration as 19 of $20(95 \%)$ patients who relapsed and were submitted to endoscopy were found to have suffered re-ulceration. On the other hand, lack of ulcer symptoms did not mean that the ulcer had remained healed, because five of $28(18 \%)$ asymptomatic patients were found to have ulcers on repeat endoscopy.

The patients who were re-endoscoped provide strong evidence that cimetidine prevented reulceration $\left(\chi^{2}=12.19, \mathrm{P}<0.001\right)$, but this cannot be accepted as absolute proof because we do not know whether or not re-ulceration occurred in the 12 patients who declined the final endoscopy. We can say, however, that, when relapse occurred, the chance of finding ulceration on endoscopy was $17 / 17$ for patients on placebo and $2 / 3$ for patients on cimetidine. And when the patients remained well the chance of finding ulceration on endoscopy was $3 / 10$ for patients on placebo and $2 / 16$ for patients on cimetidine. There is therefore no reason to suspect asymptomatic patients on cimetidine of being more liable to ulceration than asymptomatic patients on placebo - rather the reverse - and so it seems unreasonable to doubt that cimetidine promoted ulcer healing. Even if we assume the worst possible result for patients who were not re-endoscoped and imagine that none of those on placebo developed ulcers and that all of those on cimetidine did so, the

Table 1 Fate of patients who entered the maintenance trial

\begin{tabular}{|c|c|c|c|c|c|c|c|c|c|c|c|c|}
\hline \multirow[t]{3}{*}{ Treatment } & \multirow{3}{*}{\multicolumn{2}{|c|}{$\begin{array}{l}\text { No. and } \\
\text { sex of } \\
\text { patients }\end{array}$}} & \multirow[t]{3}{*}{ Defaulted } & \multirow{3}{*}{$\begin{array}{l}\text { Continued } \\
\text { in trial }\end{array}$} & \multicolumn{4}{|c|}{ Relapsed clinically } & \multicolumn{4}{|c|}{ Did not relapse } \\
\hline & & & & & \multirow[t]{2}{*}{ No. } & \multicolumn{3}{|c|}{ Result of endoscopy } & \multirow[t]{2}{*}{ No. } & \multicolumn{3}{|c|}{ Result of endoscopy } \\
\hline & & & & & & Ulcer & $\begin{array}{l}\text { No } \\
\text { ulcer }\end{array}$ & $\begin{array}{l}\text { Not } \\
\text { scoped }\end{array}$ & & Ulcer & $\begin{array}{l}\text { No } \\
\text { ulcer }\end{array}$ & $\begin{array}{l}\text { Not } \\
\text { scoped }\end{array}$ \\
\hline \multirow[t]{2}{*}{$\begin{array}{l}\text { Placebo } \\
\text { (2 tablets bd) }\end{array}$} & & $\begin{aligned} 28 \mathrm{M} \\
5 \mathrm{~F}\end{aligned}$ & $\begin{array}{l}1 \\
1\end{array}$ & $\begin{array}{r}27 \\
4\end{array}$ & $\begin{array}{r}15 \\
3\end{array}$ & $\begin{array}{r}14 \\
3\end{array}$ & $\begin{array}{l}0 \\
0\end{array}$ & $\begin{array}{l}1 \\
0\end{array}$ & $\begin{array}{r}12 \\
1\end{array}$ & $\begin{array}{l}3 \\
0\end{array}$ & $\begin{array}{l}6 \\
1\end{array}$ & $\begin{array}{l}3 \\
0\end{array}$ \\
\hline & Total & 33 & 2 & 31 & 18 & 17 & 0 & 1 & 13 & 3 & 7 & 3 \\
\hline \multirow[t]{2}{*}{$\begin{array}{l}\text { Cimetidine } \\
(2 \times 200 \mathrm{mg} \text { bd })\end{array}$} & & $\begin{aligned} 28 \mathrm{M} \\
4 \mathrm{~F}\end{aligned}$ & $\begin{array}{l}3 \\
0\end{array}$ & $\begin{array}{r}25 \\
4\end{array}$ & $\begin{array}{l}4 \\
0\end{array}$ & $\begin{array}{l}2 \\
0\end{array}$ & $\begin{array}{l}1 \\
0\end{array}$ & $\begin{array}{l}1 \\
0\end{array}$ & $\begin{array}{r}21 \\
4\end{array}$ & $\begin{array}{l}2 \\
0\end{array}$ & $\begin{array}{r}13 \\
3\end{array}$ & $\begin{array}{l}6 \\
1\end{array}$ \\
\hline & Total & 32 & 3 & 29 & 4 & 2 & 1 & 1 & 25 & 2 & 16 & 7 \\
\hline $\begin{array}{l}\text { Total of } \\
\text { both groups }\end{array}$ & & 65 & 5 & 60 & 22 & 19 & 1 & 2 & 38 & 5 & 23 & 10 \\
\hline
\end{tabular}


overall result would still be favourable to cimetidine with 17 of $29(59 \%)$ healed ulcers against 11 of 31 (35\%) on placebo.

Table 2 shows, for patients on cimetidine and placebo, that the length of previous dyspeptic history had no obvious bearing on the results of maintenance treatment with either placebo or cimetidine. In contrast, the dose of cimetidine used to heal ulcers immediately before this maintenance trial may have had a bearing on the results. Table 3 shows for 53 patients the numbers relapsing on placebo or

Table 2 Numbers of patients relapsing, classified according to length of preceding history

\begin{tabular}{|c|c|c|c|c|c|}
\hline \multirow{2}{*}{$\begin{array}{l}\text { Length of } \\
\text { history } \\
\text { (years) }\end{array}$} & \multicolumn{2}{|l|}{ Placebo } & \multicolumn{2}{|l|}{ Cimetidine } & \\
\hline & Relapsed & $\begin{array}{l}\text { Did not } \\
\text { relapse }\end{array}$ & Relapsed & $\begin{array}{l}\text { Did not } \\
\text { relapse }\end{array}$ & \\
\hline $\begin{array}{l}0 \text { to } 3 \\
3 \text { to } 10 \\
10+\end{array}$ & $\begin{array}{l}7 \\
5 \\
6\end{array}$ & $\begin{array}{l}2 \\
7 \\
4\end{array}$ & $\begin{array}{l}1^{*} \\
0 \\
3\end{array}$ & $\begin{array}{r}11 \\
6 \\
8\end{array}$ & $\begin{array}{l}21 \\
18 \\
21\end{array}$ \\
\hline & 18 & 13 & 4 & 25 & 60 \\
\hline
\end{tabular}

*No ulcer found on endoscopy.

Table 3 Numbers of patients relapsing, classified according to whether they were treated with 1 or 2 g/day of cimetidine before entry to maintenance trial

\begin{tabular}{|c|c|c|c|c|c|}
\hline \multirow{3}{*}{$\begin{array}{l}\text { Treatment for } \\
\text { I month before } \\
\text { entry to maintenance } \\
\text { trial }\end{array}$} & \multicolumn{4}{|c|}{ Maintenance treatment } & \\
\hline & \multicolumn{2}{|l|}{ Placebo } & \multicolumn{2}{|c|}{ Cimetidine } & \\
\hline & Relapsed & $\begin{array}{l}\text { Did not } \\
\text { relapse }\end{array}$ & Relapsed & $\begin{array}{l}\text { Did not } \\
\text { relapse }\end{array}$ & \\
\hline \multirow[t]{2}{*}{$\begin{array}{l}\text { Cimetidine } \\
1 \mathrm{~g} / \text { day } \\
2 \mathrm{~g} / \text { day }\end{array}$} & $\begin{array}{r}13 \\
3\end{array}$ & $\begin{array}{r}2 \\
11\end{array}$ & $\begin{array}{l}\mathbf{0} \\
\mathbf{3}\end{array}$ & $\begin{array}{r}13 \\
8\end{array}$ & $\begin{array}{l}28 \\
25\end{array}$ \\
\hline & \multicolumn{2}{|c|}{$\begin{array}{l}\mathrm{P}=0.0006 \\
\text { Fisher's exact test }\end{array}$} & \multicolumn{2}{|c|}{$\begin{array}{l}P=0.082 \\
\text { NS Fisher's } \\
\text { exact test }\end{array}$} & 53 \\
\hline
\end{tabular}

Numbers of patients are smaller than in other tables because only these patients had received cimetidine in the previous Multicentre Trial (1979). cimetidine, classified according to whether their ulcers had been healed by previous treatment with 1 or $2 \mathrm{~g}$ per day of cimetidine. It appears that those treated with $2 \mathrm{~g} /$ day were less likely to relapse on placebo than those treated with $1 \mathrm{~g} /$ day.

Table 4 shows that the mean duodenitis score deteriorated in patients who relapsed but did not do so in those who remained well. Different observers probably assessed duodenitis differently, so no attempt has been made to analyse the scores. If, however, observers were reasonably consistent in assessing duodenitis in a given patient the number of patients whose duodenitis was assessed as worse, same, or better might be expected to be related to clinical state if, indeed, duodenitis has any bearing on this. As shown below the table, there was evidence that clinical relapse was associated with worsening duodenitis.

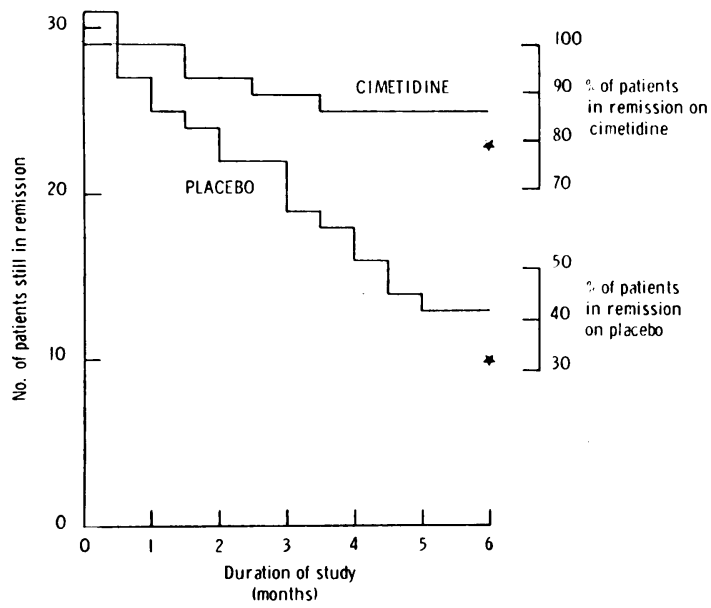

Figure Pattern of clinical relapse in patients with healed duodenal ulcers who were given maintenance treatment either with cimetidine $(400 \mathrm{mg} \mathrm{bd})$ or matching placebo. All but one of the patients who relapsed were proved to have recurrence of ulceration, and at the end of the trial endoscopy showed that five asymptomatic patients also had ulcers (asterisks).

Table 4 Duodenitis scores

\begin{tabular}{|c|c|c|c|c|c|c|}
\hline \multirow[t]{2}{*}{ Fate of patients } & \multirow[t]{2}{*}{ No. of patients } & \multicolumn{2}{|c|}{ Mean scores at endoscopy } & \multicolumn{3}{|c|}{$\begin{array}{l}\text { No. of patients whose duodenitis was } \\
\text { judged at } 2 \text { nd endoscopy to be }\end{array}$} \\
\hline & & $I$ & 2 & Better & Same & Worse \\
\hline Relapsed on cimetidine & 3 & $2 \cdot 00$ & 3.67 & 1 & $\mathbf{0}$ & 2 \\
\hline Relapsed on placebo & 15 & $3 \cdot 20$ & 4.93 & $i$ & 5 & 9 \\
\hline Remained well on cimetidine & 18 & $2 \cdot 50$ & $2 \cdot 00$ & 5 & 10 & 3 \\
\hline Remained well on placebo & 10 & $2 \cdot 70$ & 1.60 & 5 & 2 & 3 \\
\hline
\end{tabular}

Improvement in duodenitis scores was associated with the patients remaining well $\left(\chi_{2}^{2}=7.90, \mathbf{P}<0.02\right)$ but the corresponding test whether duodenitis scores were associated with cimetidine therapy failed to reach significance $\left(x_{2}^{2}=3.09\right)$.

These mean scores were obtained by taking, for each patient in a group, the sum of scores for severity and extent of duodenitis (these being usually the same). The sums of the scores were added together and divided by the number of patients in each group. 
In the Figure the stepwise fall in the number of patients remaining in clinical remission shows, in the case of those on placebo, a remorseless downward trend over six months. Cimetidine treatment was effective in preventing this but did not confer complete immunity. Moreover, endoscopy at the end of six months discovered a total of five unsuspected ulcers (two in the cimetidine group and three in the placebo group) as indicated by the asterisks. Thus, although cimetidine was clearly superior to placebo, reulceration occurred in at least $21 \%$ of patients treated for six months with $800 \mathrm{mg} /$ day.

Untoward symptoms unrelated to ulcer disease were reported by 14 patients (seven on cimetidine, seven on placebo); none of these symptoms required the patient's withdrawal from the trial. No symptom occurred consistently in either treatment group, as shown in Table 5. There were no withdrawals from the study because of abnormal laboratory results. Abnormal biochemical values occurring in each patient are summarised in Table 6. The table represents the total experience and isolated abnormal values of no clinical significance are included. Four cimetidine-treated patients were found to have clinically significant rises in serum transaminases. One, a 61 year old man, developed an SGOT of 57 IU/1 (normal <32) and a $\gamma$-GT of 182 IU/l (normal $<45$ ) after four weeks' treatment; these changes were associated with myalgia, fever, a raised sedi-

Table 5 Numbers of patients complaining of symptoms

\begin{tabular}{lll}
\hline & Cimetidine & Placebo \\
\hline Reflux & 2 & 5 \\
Teichopsia & - & 1 \\
Increased appetite & - & 1 \\
Drowsiness & - & 1 \\
Headache & 1 & 3 \\
Musculoskeletal pain & 3 & 1 \\
Depression & - & 2 \\
Dry skin/hair & - & 1 \\
Vomiting & - & 1 \\
Rash & 1 & - \\
Abdominal pain (non-ulcer type) & 1 & - \\
\hline
\end{tabular}

mentation rate and a normocytic normochromic anaemia. He was considered to have a viral illness, and he became completely asymptomatic with a return of the laboratory values to normal on continued treatment. Two other patients, both males with a history of high alcohol intake, developed moderate rises in transaminases; one was known to have alcoholic cirrhosis and had abnormal liver function before treatment. The fourth patient, a 48 year old man, had an SGOT of $410 \mathrm{IU} / 1$ (normal < 32 ) on entry to the trial, but this value had returned to normal by the fourth month of treatment. There were no haematological abnormalities encountered, other than changes in haemoglobin or associated indices which could be attributed to the underlying ulcer disease. In particular, there were no significant falls in the white blood count or platelet count. No unexpected urinary abnormalities occurred.

\section{Discussion}

Allocation of patients at random to treatment with cimetidine or placebo produced two groups of patients who were similar in sex distribution, age, duration of symptoms, drinking and smoking habits. It is therefore extremely unlikely that the different clinical course of patients in the two treatment groups was due to factors other than treatment with, or without, cimetidine. The trial showed that cimetidine in a dose of $400 \mathrm{mg}$ in the morning, and at bedtime over a six month period significantly reduced the rate of clinical relapse. Cimetidine also (almost certainly) prevented re-ulceration, but we cannot feel totally confident of this because some patients who were asymptomatic declined endoscopy to confirm that their ulcers were still healed. Our results are thus similar to those of Gudmand-Høyer et al. (1978) who followed their patients for one year but who had, at six months, only $1 / 26(4 \%)$ of relapses-a proportion not significantly different from what we found. Bodemar and Walan (1978) followed their patients for a year at which time six of

Table 6 Abnormal biochemical values occurring during treatment

\begin{tabular}{|c|c|c|c|c|c|c|c|c|}
\hline & \multicolumn{8}{|c|}{ Abnormal laboratory values } \\
\hline & \multicolumn{4}{|c|}{ Developing during treatment } & \multicolumn{4}{|c|}{ Before treatment } \\
\hline & \multicolumn{2}{|c|}{ Remaining abnormal } & \multicolumn{2}{|c|}{ Returning to normal } & \multicolumn{2}{|c|}{ Remaining abnormal } & \multicolumn{2}{|c|}{ Returning to normal } \\
\hline & $C$ & $P$ & $C$ & $P$ & $C$ & $\boldsymbol{P}$ & $C$ & $P$ \\
\hline Urea & - & - & 2 & 2 & - & - & 一 & - \\
\hline Urate & 1 & 2 & 4 & 1 & 5 & 3 & 一 & 一 \\
\hline SGPT & 1 & 1 & 1 & 4 & 2 & - & - & 一 \\
\hline SGOT & - & 1 & 2 & 1 & 1 & - & 一 & - \\
\hline$\gamma-\mathbf{G T}$ & 1 & 1 & 2 & - & - & - & - & - \\
\hline Bilirubin & - & 1 & 3 & 3 & - & - & - & - \\
\hline Alk. phosphatase & - & - & 2 & 1 & 一 & - & - & - \\
\hline
\end{tabular}


$32(19 \%)$ of their patients had re-ulcerated, although not all had severe symptoms. It is therefore clear that our results are not atypical in showing that maintenance therapy with cimetidine confers benefit which, however, falls short of complete immunity from further trouble.

Duodenitis became more marked in patients who relapsed and re-ulcerated but the data do not help to elucidate the relationship between duodenitis, ulceration, and pain. It is interesting, however, to note that the fate of patients in the maintenance trial seems to have been partly determined by the dose of cimetidine used in the initial healing of their ulcers. Those who had $2 \mathrm{~g} /$ day initially did far better than those who had only $1 \mathrm{~g} /$ day if they were subsequently given placebo $(\mathrm{P}<0.001)$. If, however, the maintenance treatment was with cimetidine this effect was no longer seen. This is strange because at the start of the maintenance trial all the ulcers were seen to have healed by endoscopy; we had not anticipated the possibility that some healed ulcers might be more firmly healed than others-especially since the Multicentre Trial (1979) showed no significant difference between the proportions of ulcers healing on 1 and $2 \mathrm{~g}$ cimetidine daily.

Cimetidine appeared to be safe: no patient was withdrawn because of unwanted effects. In contrast with the findings in short-term trials, rises in serum creatinine were no more common in cimetidine-treated patients than in those who had placebo (see, for example, Multicentre Trial, 1979). Rises in serum uric acid and liver enzymes were likewise not significantly more common in patients on cimetidine than in those on placebo. Although four cimetidinetreated patients in our series exhibited rises in serum levels of liver enzymes, the changes were transient in two of them and were not progressive in the other two, in whom alcohol was undoubtedly an important factor.

There has been speculation that withdrawal of treatment with an $\mathrm{H}_{2}$-receptor antagonist results in severe and rapid recurrence of ulceration (Saunders and Wormsley, 1977) but, quite apart from lack of evidence for a gastrin-mediated trophic effect of cimetidine in man (Spence et al., 1978) or of a rebound in acid secretion (Bodemar and Walan, 1978), neither our data (in the Figure) nor those of
Gudmand-Høyer et al. (1978) show a relapse rate on withdrawing cimetidine which is demonstrably greater immediately after withdrawing the drug than it is a month or two later.

So, if severe and sudden relapses do in fact occur on stopping cimetidine they must be sufficiently rare not to have any visible effects on the results in two groups each of about 30 patients.

We are grateful to Smith, Kline \& French, Ltd, for providing cimetidine and placebo, and for their randomisation; and to Miss Diana Wilson for typing the manuscript.

\section{References}

Bardhan, K. D., Blum, A., Gillespie, G., Larkworthy, W., Mekel, R., Moshal, M., Smith, P. M., Venables, C. W., Van Tongeren, J. H. M., and Walan, A. (1977). Long-term treatment with cimetidine in duodenal ulceration (Letter). Lancet, 1, 900-901.

Blackwood, W. S., Maudgal, D. P., Pickard, R. G., Lawrence, D., and Northfield, T. C. (1976). Cimetidine in duodenal ulcer. Controlled trial. Lancet, 2, 174-176.

Bodemar, G., and Walan, A. (1976). Cimetidine in the treatment of active duodenal and prepyloric ulcers. Lancet, 2, 161-164.

Bodemar, G., and Walan, A. (1978). Maintenance treatment of recurrent peptic ulcer by cimetidine. Lancet, 1, 403-407.

Gray, G. R., Mackenzie, I., Smith, I. S., Crean. G. P., and Gillespie, G. (1977). Oral cimetidine in severe duodenal ulceration-a double-blind controlled trial. Lancet, 1, 4-7.

Gray, G. R., Smith, I. S., Mackenzie, I., and Gillespie, G. (1978). Long term cimetidine in the management of severe duodenal ulcer dyspepsia. Gastroenterology, 74, 397-401.

Gudmand-Høyer, E., Birger Jensen, K., Krag, E., RaskMadsen, J., Rahbek, I., Rune, S. J., and Wulff, H. R. (1978). Prophylactic effect of cimetidine in duodenal ulcer disease. British Medical Journal, 1095-1097.

Hetzel, D. J., Hansky, J., Shearman, D. J. C., Korman, M. G., Hecker, R., Taggart, G. J., Jackson, R., and Gabb, B. W. (1978). Cimetidine treatment of duodenal ulceration. Gastroenterology, 74, 389-392.

Multicentre Trial (1979). A comparison of two doses of cimetidine and placebo in the treatment of duodenal ulcer. Gut, 20, 68-74.

Saunders, J. H. B., and Wormsley, K. G. (1977). Long-term effects and after-effects of treatment of duodenal ulcer with metiamide. Lancet, 1, 765-767.

Spence, R. W., Celestin, L. R., McCormick, D. A., Owens, C. J., and Oliver, J. M. (1978). The effect of long-term treatment with cimetidine on gastric acid secretion and gastrin responses in man. International Symposium on Histamine $\mathrm{H}_{2}$-receptor Antagonists, Gottingen, Germany. p. 116. Excerpta Medica: Amsterdam. 